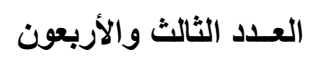

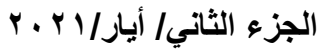

تقديم الذات وعلاقته بالكفاءة الشخصية لاى طلبة الجامعة

\section{جامسـعة واســـ}

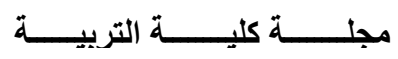

أ.م.د. صبيحة ياسر مكطوف

جامعة الموصل/ كلية التربية للعلوم الانسانية

الملخص

أستهدف البحث تعرف كل من تقديم الذات والكفاءة الثخصية لدى طلبة الجامعة والعلاقة

بينهما والكثف عن الفروق في تقديم الذات وفقاً لمتغير (الجنس - التخصص) وكذلك الفروق في الكفاءة الثخصية وفقاً لمتغير (الجنس - التخصص)، وبلغت عينة البحث الاساسية ( . ب) طالبا وطالبة بواقع (10.0) ذكور و(0.0) إناث، وتم استخدام مقياس جاهز لتقديم الذات والمعد من قبل(يارنظر وهيثم) في حين اعدت الباحثة مقياس للكفاءة الثخصية، وقد تم معالجة البيانات بإستخدام الحقيبة الأحصائية (SPSS)، وتوصل البحث الى النتائج الآتية إن مستوى تقديم الذات لدى طلبة الجامعة ضمن المستوى المتوسط وكذلك الكفاءة الثخصية لدى طلبة الجامعة، وإن هناك علاقة دالة احصائياً بين تقديم الذات والكفاءة الثخصية لدى طلبة الجامعة، ويوجد فرق دال احصائياً في تقديم الذات تبعا لمتغير الجنس ولصالح الذكور وكذلك عدم وجود فرق دال احصائي تبعا للتخصص، لئ

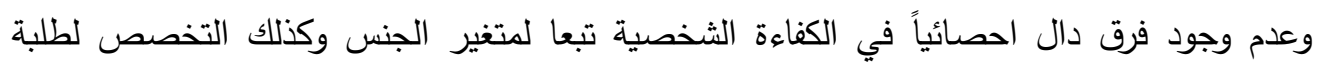
الجامعة، وقد وضعت الباحثة عدد من التوصيات منها ضرورة اهتمام وزارة التعليم العالي بإقامة دورات تسهح في رفع مستوى تقديم الذات لاى الطلبة، كما أسفرت النتائج عن عدد من المقترحات منها أجراء دراسة عن تقديم الذات وعلاقته بالإنجاز الدراسي لدى طلبة الجامعة. الكلمات المفتاحية: (تقديم الذات - الكفاءة الشخصية - طلبة الجامعة) 


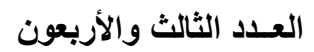

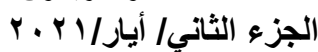

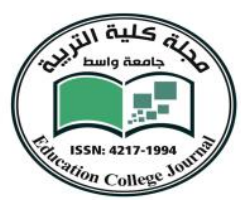

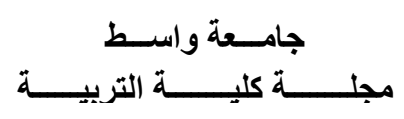

Self-Presentation and Its Relationship to Personal Competence among University Students

Asst. Prof. Sabeeha Yaser Maktoof

University of Mosul/ College of Education for Humanities

Dept. of Educational and Psychological Sciences

\begin{abstract}
The aim of the research is to identify both the self-presentation and the personal competence of university students, test the relationship between them and to reveal the differences in self-presentation according to the variable (gender - specialization) as well as the differences in personal competence according to the variable (gender - specialization). The basic research sample is (300) male and female students: (150) males and (150) females. A self-presentation scale which was used by (Yarzer and Haitham) has been adopted in this research. While the researcher prepared a measure of personal competence. The data were processed using the statistical means (SPSS). The researcher finds that:

The level of self-presentation among university students is within the average level, as well as the personal competence of university students. There is a statistically significant relationship between self-presentation and personal competence among university students. There is a statistically significant difference in self-presentation according to the gender variable and in favor of males, as well as there is no statistically significant difference according to specialization. There is no statistically significant difference in personal competence according to the gender variable, as well as the specialization of university students. The researcher put forward a number of recommendations, including the need for the Ministry of Higher Education to pay attention to the establishment of courses that contribute to raising the level of self-presentation of students. The researcher also set a number of suggestions, including conducting a study on self-presentation and its relationship to academic achievement among university students.
\end{abstract}

(Self-Presentation -Personal Competence- University Students) 


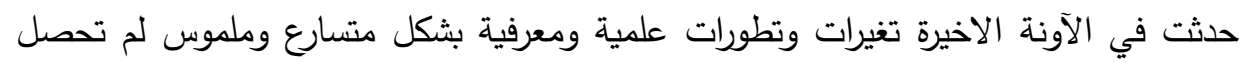

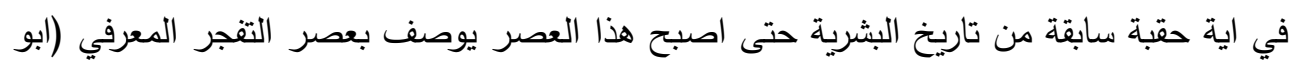

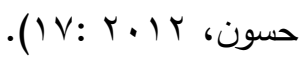

وتعد هذه التغيرات والثورة التكنولوجية وغزارة المعلومات جعلت الفرد امام عوالم مختلفة ومتناقضة ولا سيما انه يواجه ثقافات عديدة قد يكون البعض منها غير مألوف في مجتمعنا مما يقوده لمواجهة

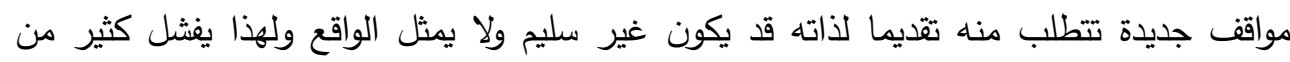

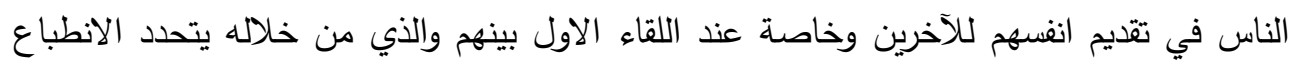

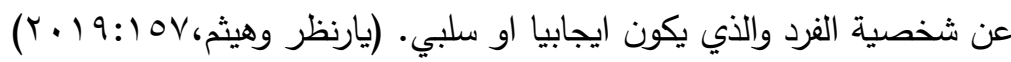

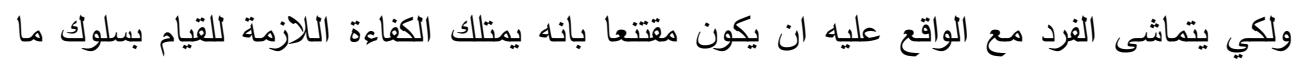

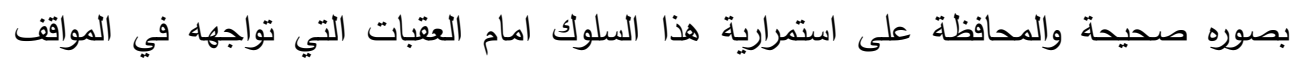

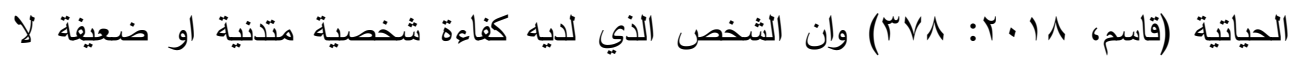
يستطيع تطوير قدراته الخاصة بالتخطيط وتتفيذ المهام فمعتقدات الفرد عن نفسه اساس مهم لتحديد

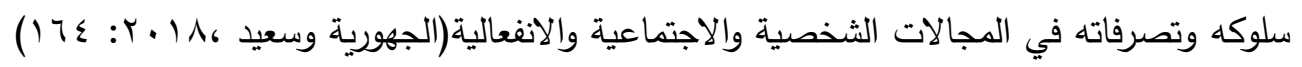
وفي حالة عدم اقتناعه بذلك فأنه يشعر بخيبة الامل وضعف الثقة بالذات مما ينعكس بصورة سلبية على تقديمه لذاته وكفاءته الثخصية. تتضح مشكلة البحث في التساؤلات الآتية

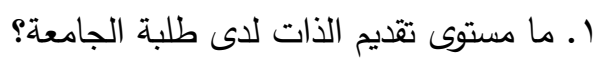

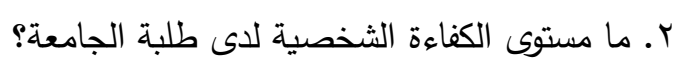

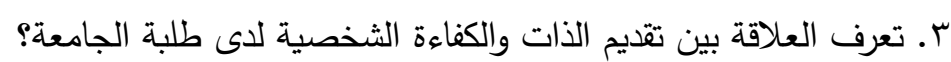
أهمية البحث : تعرف البعاء

يرى جونز ان تركيب بناء الذات "Self-construction" لتقديم الذات لا يعني ان الذات

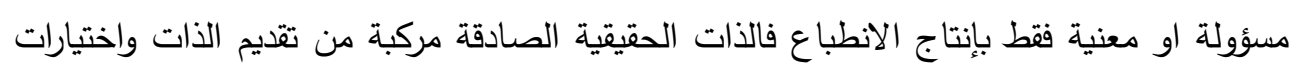
وافعال وآداءات بمعنى ان الفرد يهتم بخلق نموذج لهذا التقديم في مخيلة وعقول الاخرين

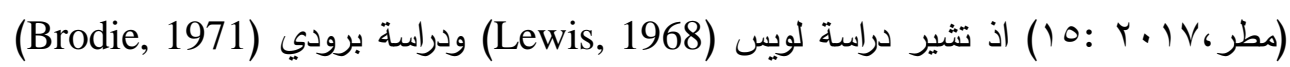

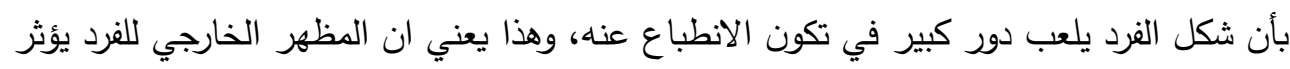
في حب الاخرين له اذ ان جاذبية الثخص واناقته لها دور كبير في تحديد شخصيته وهذا ما يقوم لـانه 


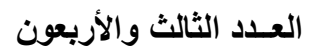

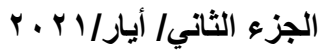

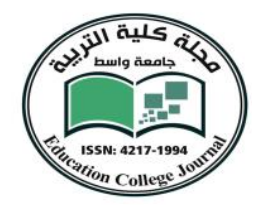

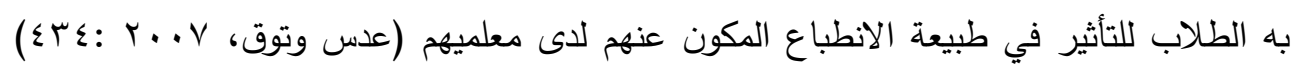
ويميل الى التعامل مع الحاضرين على اساس الانطباع الذي يعطونه في اللحظة الحاضرة عن الماضي والمستقبل (العوافي، ب ت :r) ويشير (هوكان Hogan و جونز Jones و جيك Cheek 1985) ان كل التصرفات والافعال الاجتماعية لها عناصر رمزية، كل شيء نفعله من الممكن ان يفسر في سياق تقديم الذات، الملابس التي نرتديها الكتب التي نمتلكها، الموسيقى التي نفضلها، وظائفنا، اصدقائنا وهو يشير الى الكيفية التي نريد ان ينظر الينا بها وبالطبع يلاحظ الاخرون كل

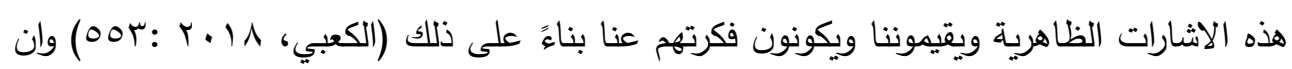
الكثف عن الذات هو رسالة يتبادلها الفرد مع الاخرين، وهو مفتاح تطور العلاقات الشخصية والتي تزيد من التقارب وتلعب دورا مهما في تتمية العلاقات (Heino, 2006: 158). وتقديم الذات هو أحد أهم نواحي الذات الخاصة بالعلاقات بين الأشخاص وهو يعني كيف

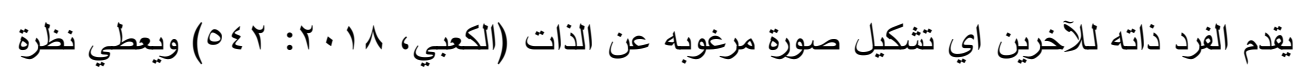
ثاقبه لطبيعة التفاعل الثخصي، إذ يقوم الفرد في المواقف بأكثر من دور ومع كل دور تختلف

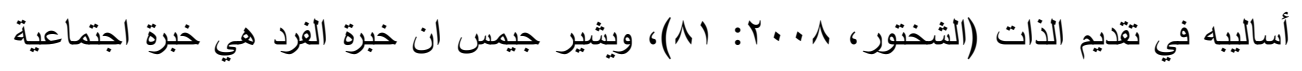

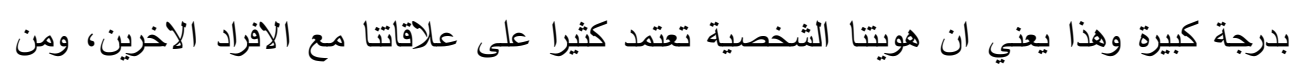
الافكار المركزية له عن الذات هو ان كل شخص لا يمتلك ذاتا واحدة بل عدة ذوات، فالثاب الذي الذي

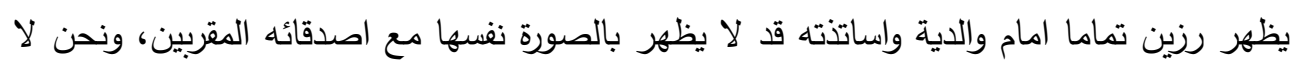
نظهر ذواتتا لأطفالنا كما نظهرها لأصدقاء في النادي او لمسؤولينا وموظفينا في اماكن العمل

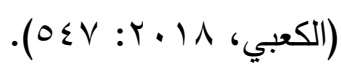
يرى بولينو وتيرنلي (Bolino \& Tumley, 1999) ان تقديم الذات يتكون من أثنين وعشرين بنداً

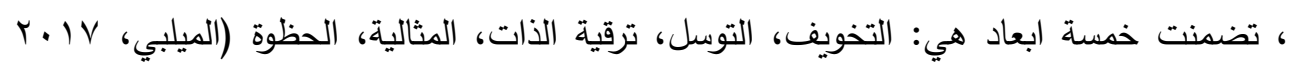

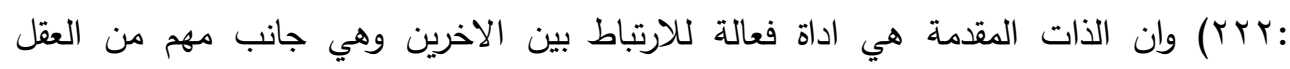
الاجتماعي ولتقديم الذات اثر كبير في زيادة الدافعية للعمل والابداع وتأثيرات على جوانب العلاقات

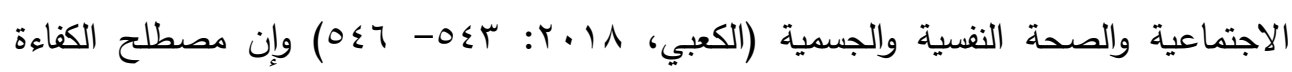
الثخصية يمثل مكونا حاسما في احساس الفرد بالضبط الشخصي والسيطرة على مستقبلة والتوافق مع احداث الحياة، وتظهر معتقدات الفرد من خلال الإدراك المعرفي للقدرات الثخصية والخبرات المتعددة سواء المباشرة او غير مباشرة ولذا فالكفاءة الذاتية يمكن أن تحدد المسار الذي يشير الى الى

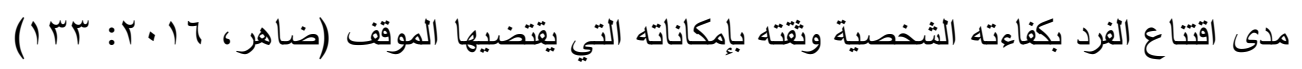




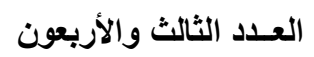

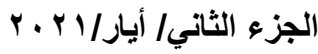

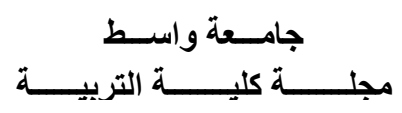

لمواجهة الضغوط والصعوبات ولهذا تؤثر على الاداء وعلى وضع الاهداف الثخصية والتفكير السليم، وان الشعور العالي بالكفاءة الشخصية يحسن العمليات المعرفية والتحصيل ويسهل اتخاذ القرار في المواقف المختلفة ويختار الافراد ذو الكفاءة العالية اداء مهام تحدى اكبر ويضعون لأنفسهم اهدافا عليا ويبذلون جها اكبر ويتوقعون احداثا تفاؤلية او تثاؤمية حسب مستوى كفاءتهم، ويقوم اصحاب الكفاءة العالية بتركيب المواقف بطرق تجلب النجاح وهم يتجنبون وضع الاشخاص بمواقف قد يفشلون فيها، وان النجاح المتوقع للفرد يقاس من خلال عنصرين الاول استطيع تقديم نفسي بالطريقة التي افضلها والثاني اعتقد اني اتمكن من اعطاء انطباع جيد عن نفسي للآخرين

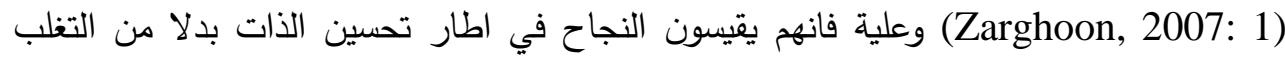
على الاخرين، وكلما زاد اعتقاد الفرد بامتلاكه سلوكيات توافقية فأنه يتمكن من حل المشكلات التي

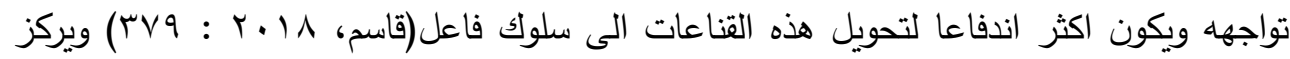
المنحى السلوكي المعرفي على كيفية ادراك الثخص للأحداث البيئية وتفسير الثخص ذاته لسلوكه وتبريره لله وانتهجت اساليب تعديل السلوك الانساني الى ما عرف باسلوب اعادة البناء المعرفي والتعليم الذاتي والهدف الاساس لهذه الاساليب هو تطوير القناعة لدى الفرد بالكفاءة الثخصية

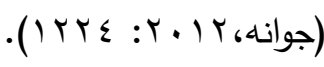

ويعد طلبة الجامعة من اكثر شرائح المتجمع قدرة على البذل والعطاء بحكم تكوينهم الجسمي الذي يجعلهم في عنفوان الحيوية والنشاط لذا تعد المرحلة الجامعية مرحله دقيقة وحاسمة حيث يقف الثباب الجامعي على مفترق الطريق بين المراهقة المتأخرة والرشد المبكر اذ يعمل من اجل

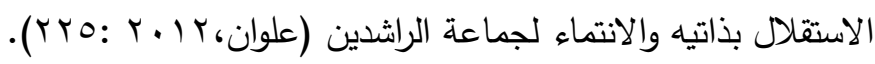
اهداف البحث: يستهدف البحث تعرف ا-تقديم الذات لدى طلبة الجامعة. r- الكفاءة الشخصية لدى طلبة الجامعة. r- العلاقة بين تقديم الذات والكفاءة الثخصية لدى طلبة الجامعة. ع-الفروق ذات الدلالة الاحصائية في العلاقة بين تقديم الذات لدى طلبة الجامعة وفقا لمتغير (الجنس - التخصص). ه-الفروق ذات الدلالة الاحصائية في العلاقة بين الكفاءة الثخصية لدى طلبة الجامعة وفقا لمتغير (الجنس - التخصص). حدود البحث: تقصر حدود البحث على: 


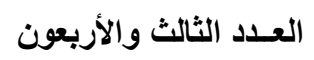

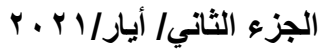

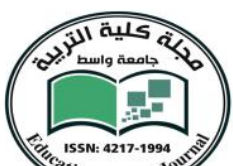

rion College

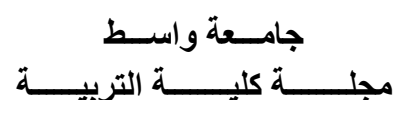

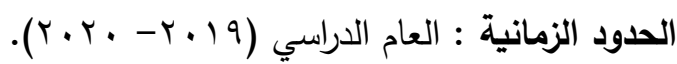

الحدود المكانية : جامعة الموصل الدراسة الصباحية.

الحدود البثرية : طلبة جامعة الموصل من كلا الجنسين.

الحدود المعرفية : تقديم الذات وعلاقته بالكفاءة الثخصية.

تحديا المصطلحات:

اولا: تقديم الأات: عرفها كل من

اركن (Arkin1980):

"الطرائق والاساليب التي تستخدم للتأثير على الانطباعات التي يكونها الاخرون عنا".

(Arkin,1980: 161)

\section{• جونز (Jones \& pittman 1982):}

"عبارة عن اساليب يستخدمها الفرد اما ان تكون تعبيرات شفوية او سلوكا لاحراز انطباعا لدى الاخرين فأن هذه الانطباعات تتطلب مجهودا من هؤلاء الافراد تترك اثر لدى الاخرين".

$$
\begin{aligned}
& \text { (يارنظر وهيثم، } 19 \text { • ب : • 1 1 ) }
\end{aligned}
$$

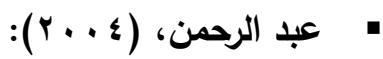

"محاولة خلق انطباع مرغوب لاى الاخرين سواء كان هذا الانطباع صحيحا او غير صحيح".

$$
\begin{aligned}
& \text { (الشختور ، ^ . . ץ: • (1) }
\end{aligned}
$$

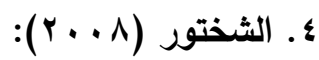

"ان تقديم الذات تعنى بتشكيل انطباعات جيدة لكي يكسب الفرد مزيدا من القوى والتأثير والاستحسان كما يهتم معظم الناس بنقل صورة ايجابية عنهم ويرغب الافراد في ان يظهروا بالثكل

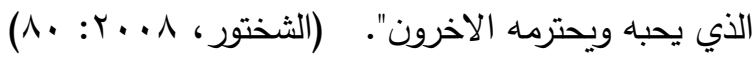

$$
\begin{aligned}
& \text { التعريف النظري لتقديم الذات: } \\
& \text { تبنت الباحثة تعريف جونز (9ᄉr ( ). } \\
& \text { التعريف الإجرائي: }
\end{aligned}
$$

"الدرجة الكلية التي يحصل عليها الطالب (المستجيب) من خلال اجابته على فقرات مقياس تقديم 


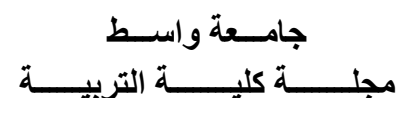

ثانيا :الكفاءة الشخصية:

"احكام الفرد او توقعاته عن ادائه للسلوك في مواقف تتسم بالغموض وتتعكس هذه التوقعات على اختيار الانشطة المتضمنة في الاداء والجهد المبذول ومواجهة الصعاب انجاز السلوك".

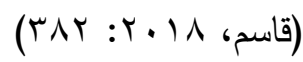

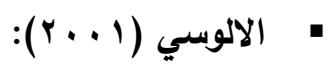

"احكام الفرد بخصوص قدراته الذاتية والناتجة من المحصلة الكلية لخبرات النجاح والفشل في حياته بشأن مبادرته للقيام بسلوك معين وبالجهد الذي يبذله في ذلك السلوك وبمثابرته علية رغم المعيقات

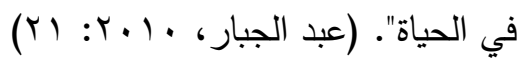

$$
\begin{aligned}
& \text { داهم (r. }
\end{aligned}
$$

"ربط اعتقادات الفرد بالكفاءة الذاتية والدافعية والانجازات الثخصية بالاعتماد على القدرات التي

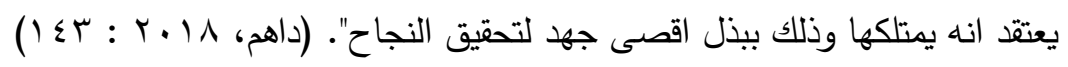

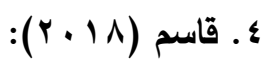
" كل ما يعتقد الفرد انه يمتلكه من امكانات تمكنه من ممارسة ضبط قياسي لقدراته وافكاره ومشاعره وافعاله وهذا الضبط القياسي يمثل الاطار المرجعي للسلوكيات التي تصدر عنه في

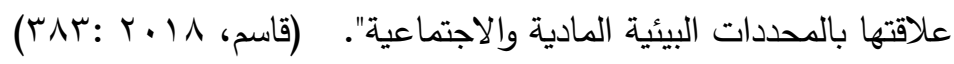
التعريف النظري للكفاءة الشخصية:

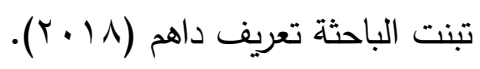
التعريف الإجرائي:

"الدرجة الكلية التي يحصل عليها الطالب ( المستجيب) من خلال اجابته على فقرات مقياس الكفاءة الشخصية الذي اعدته الباحثة". 


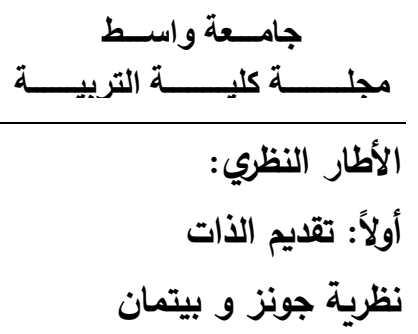

قدم جونز وبيتمان (Jones and Betman،1982) خمس استراتيجيات لتقديم الذات فالفرد

يمكن تقديم ذاته في واحدة من هذه الفئات وهي:

ا ( القبول والاستحسان (Ingratiation)

وهي أستراتيجية يستخدمها الناس لقبولهم بين الاخرين بوصفهم اشخاصا محبوبين وتتطلب بعض الحذر لأنه ربما يعتقد بعض الافراد ان هؤلاء متملقون.

r. ب. التخويف (Intimidation)

ويتخدمها الافراد لغرض تخويف الاخرين حتى لا تتيح لهم الفرصة للتراجع والصورة الأكثر شيوعا للتخويف هي التهديد. ب.التمثيل (exemplification) ويعتمدها الافراد اسلوب لتقديم الذات لكي ينظر اليهم الاخرون على انهم اخيار ويضحون بأنفسهم وصادقون تجاه الاخرين.

ع.التوسل (Supplication)

هي أسلوب لتقديم ذات معتمدين على اظهار ضعفهم وعجزهم واستغلال هذا الضعف للوصول الى الأهداف.

هـ ترقية الذات (Self -promotion)

يستخدمها بعض الافراد لعرض مهاراتهم العقلية والثخصية والاجتماعية وهي استراتيجية يمكن من خلالها ان يحقق الافراد الاحترام بين الاخرين والثبات في المواقف والسلوك الايجابي

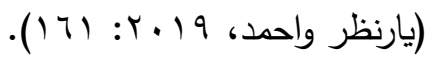
بينما هنري ليون اكد على وجود سبعة استراتيجيات وهي: اولا : القبول ( Ingratiation) ثانيا: التخويف (Intimidation) ثالثا: التوسل (Supplication) رابعا: التمثيل (exemplification) خامسا: الاستحقاق (Entitlement) 


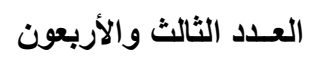

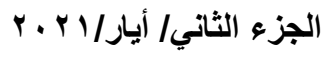
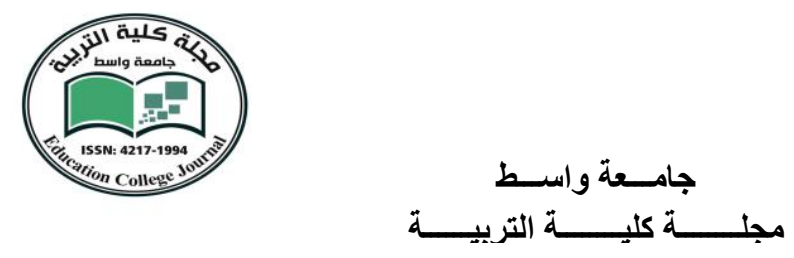

سابعا: المندفع (Blasting)

سادسا: التعزيز (Enhancement) (Honoree leon,1999)

ثانياً: الكفاءة الشخصية

نظرية التعلم الاجتماعي (بندول)

يرى بندورا ان معتقدات الفرد عن فاعلية الذاتية تظهر من خلال الادراك المعرفي للقدرات الثخصية

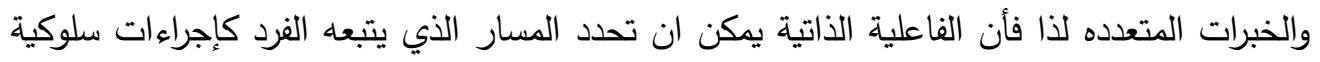

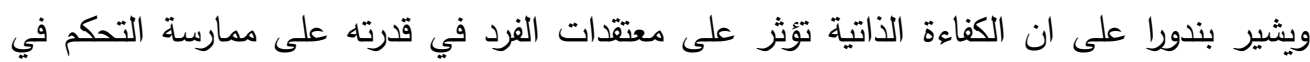

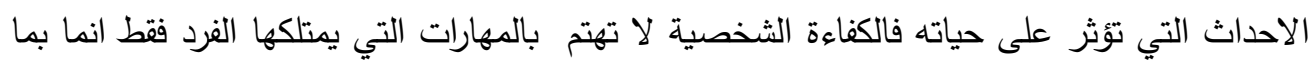

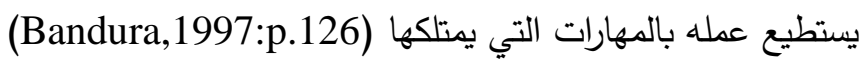
يرى بندورا ان الافراد الذين ينظرون لأنفسهم كفعل مؤثر عالي يختلفون في شعورهم وتفكيرهم عن

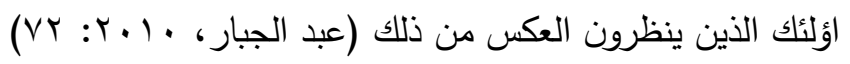
الاراسات السابقة: - الابن اولا: الاراسات التي تناولت تقديم الذات

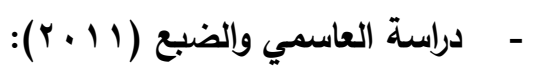

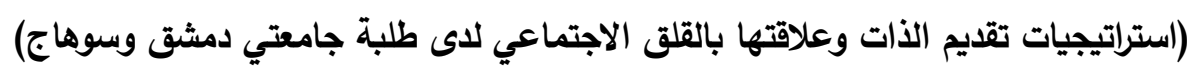

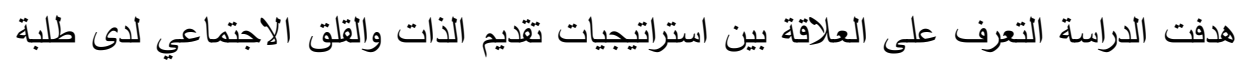

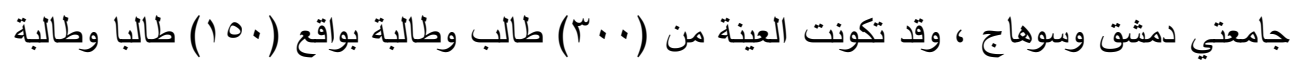

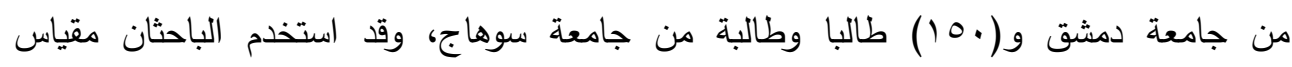

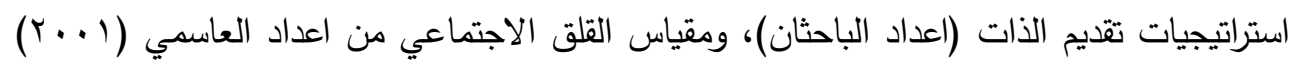

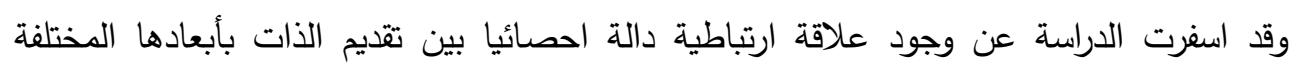

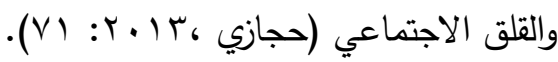

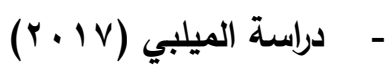

(النموذج البنائي للنزعة للمحاجة وتقديم الذات والسلوك القيادي لدى ذوي الادوار الاشرافية في

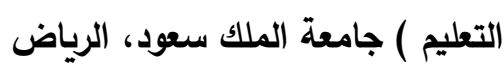

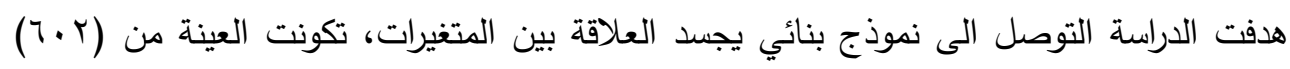

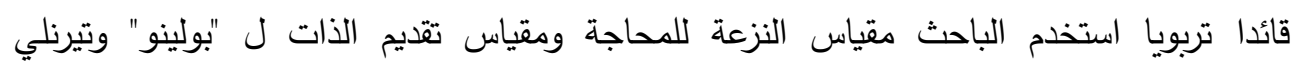

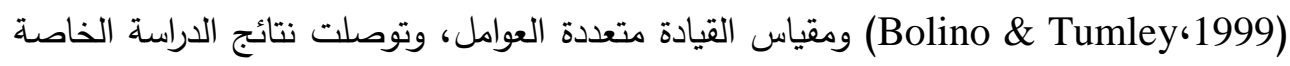




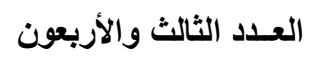

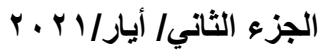

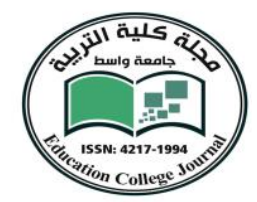

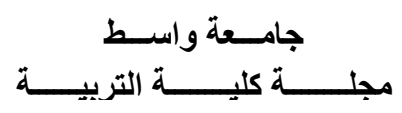

باختبار النموذج البنائي المقترح الى ان المتغير المستقل النزعة للمحاجة يساهم مساهمة داله احصائيا بشكل مباشر وغير مباشر في التتبؤ بالأنواع الثلاثة للسلوك القيادي (القيادة التحويلية والقيادة التبادلية والقيادة الترسلية) كمتغيرات تابعة عبر ابعاد تقديم الذات كمتغيرات وسيطية وهي:

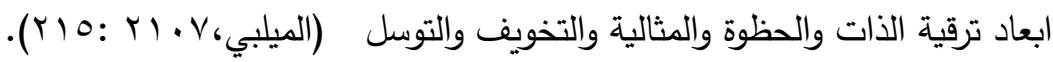

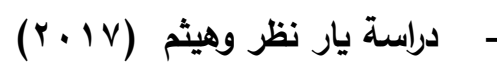
(تقديم الأات عند طلبة الجامعة) ديالى، العراق لمات هدفت الدراسة التعرف على تقديم الذات عند طلبة الجامعة ودلالة الفروق الاحصائية في تقديم الذات عند طلبة الجامعة بحسب الجنس والتخصص، تكونت العينة من ( . . ع) طالبا وطالبة من

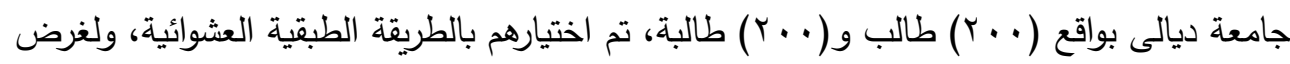
تحقيق اهداف الدراسة قامت الباحثة ببناء مقياس تقديم الذات ويتألف المقياس من (•r) فقرة وتم التحقق من الصدق الظاهري وصدق الأداة والثبات وتم استخدام وسائل احصائية الاختبار التائي لعينة واحده والاختبار التائي لعينتين مستقلتين، تحليل التباين الثنائي بتفاعل، وتم التوصل الى النتائج الاتية: يتمتع طلبة الجامعة بمستوى متوسط من تقديم الذات، ولا توجد فروق في تقديم

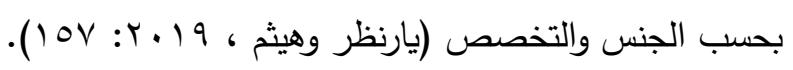
ثانيا: الاراسات التي تناولت الكفاءة الثخصية:

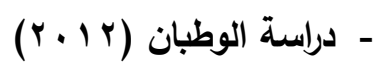

(ابعاد الكفاءة التدريسية الثخصية للمعلم دراسة مقارنة وفقا للجنس وسنوات الخبرة والمرحلة (التعليمية) جامعة القصيم هدفت الدراسة الى الكثف عن اثر اختلاف الجنس (معلمين - معلمات) والمرحلة التعليمية (ابتدائية ومتوسطة وثانوية وسنوات الخبرة على ابعاد الكفاءة التدريسية الثخصية (الثرح، النظام، التعاون، التحفيز، التكيف) لدى عينة من المعلين والمعلمات بمنطقة القصيم التعليمية، تكونت العينة (^^^§) معلما ومعلمة تم اختيارهم بالطريقة العشوائية، وتم تطبيق مقياس الكفاءة الذاتية التدريسية على افراد العينة ودلت النتائج على: - عدم وجود فروق ذات دلالة احصائية بين المعلمين والمعلمات في الكفاءة التدريسية الثخصية المتعلقة بالثرح و بالمحافظة على النظام، بينما ظهرت فروق دالة احصائيا فيما يتعلق بالكفاءة التدريسية الثخصية المتعلقة بالتحفيز وبالتكيف مع المتغيرات والتحديات لصالح المعلمات. 


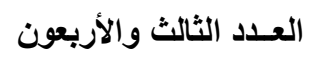

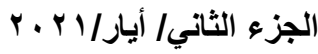

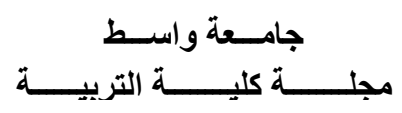

- عدم وجود فروق ذات دلالة احصائية بين افراد عينة الدراسة حسب المرحلة التعليمية في الكفاءة التدريسية الشخصية المتعلقة بالشرح والمتعلقة بالمحافظة على النظام. - عدم وجود فروق ذات دلالة احصائية بين افراد عينة الدراسة تبعا لسنوات الخبرة في بعد الكفاءة التدريسية الثخصية المتعلقة بالمحافظة على النظام وبعد التحفيز ومراعاة الفروق الفردية للطلاب

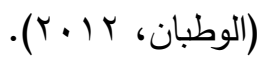

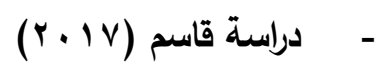

(الكفاءة الشخصية وعلاقتها باليقظة الذهنية لاى طلبة الجامعة ) المستنصرية العراق هدفت الدراسة الى معرفة الكفاءة الشخصية ومستوى اليقظة الذهنية لدى طلبة الجامعة وكذلك لهاءك معرفة دلالة الفروق على وفق النوع (ذكور - اناث ) فضلا عن العلاقة الارتباطية بين المتغيرين ، ودية تكونت العينة ( • Y ) طالبا وطالبة وتم اختيارهم عشوائيا من ثلاثة كليات في الجامعة المستتصرية عبد)

وقامت الباحثة بتبني مقياس الكفاءة الشخصية المعد من قبل

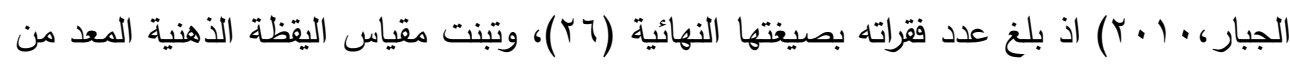

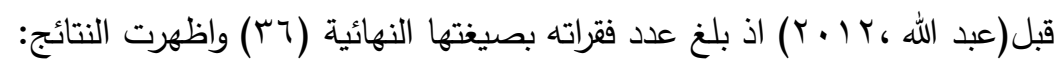
- ان عينة الدراسة من طلبة الجامعة ليس لديهم كفاءة شخصية. - لا توجد فروق ذات دلالة احصائية بين الذكور والاناث في الكفاءة الثخصية. - ان عينة الدراسة من طلبة الجامعة يوجد لديهم يقظة ذهنية. - ل الوجد علاقه ارتباطية دالة بين الكفاءة الشخصية واليقظة الذهنية تبعا للعينة ككل.

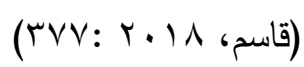

$$
\text { إجراءات البحث }
$$

وتثمل المنهج المعتمد ومجتمع البحث وعيناته والادوات المستخدمة ومؤشرات الصدق والثبات والوسائل الاحصائية المستخدمة لمعالجة البيانات احصائيا وعلى النحو الاتي: أولا: منهجية البحث

تم استخدام المنهج الوصفي العلائقي ويعرف المنهج الوصفي بأنه اجراء مسحيي من اجل

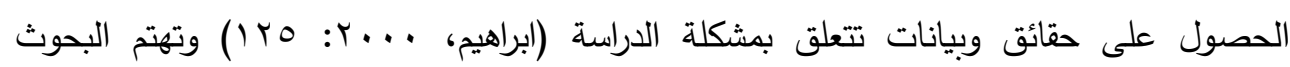
الوصفية بالكثف عن العلاقة بين متغيرين او اكثر لمعرفة مدي الارتباط بين هذه المتغيرات

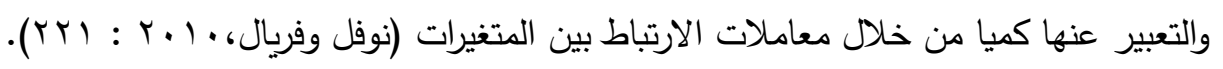




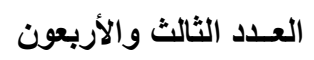

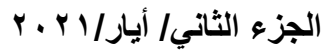

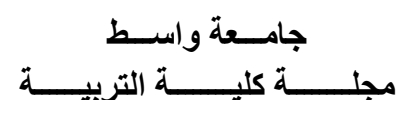

ثانيا: مجتمع البحث

تم تحديد مجتمع البحث المتمثل بطلبة جامعة الموصل في الكليات العلمية والانسانية للعام

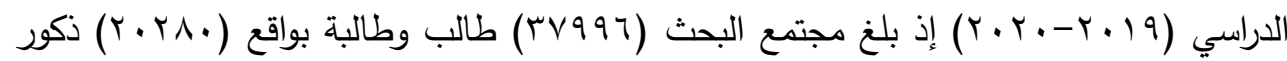
و) (IVVI 9 (إناث. ثالثا: عينات البحث: أ. عينة التطبيق الاستطلاعي: عابنات: التصا:

إن الهدف الأساسي من اعتماد العينة الاستطلاعية هو التعرف على الصعوبات التي تعترض الباحثة اثثاء تطبيق ادوات بحثها ومعرفة الوقت المستغرق عند الاجابة والكثف عن الفقرات الغامضة وغير الواضحة والتأكد من وضوح التعليمات الخاصة بكيفية الاجابة فضلا عن الاستفادة منها في جمع بعض الفقرات لمقياس تقديم الذات فقد اختيرت عينة عشوائية من كلية التربية بلغ مجموعها ( • ع) طالبا وطالبة. ب. بعتة الثبات:

لغرض استخراج ثبات اداتي البحث بطريقة التطبيق واعادة التطبيق سحبت عينة الثبات وبلغت ( • (7) طالبا وطالبة تم اختيارهم بالطريقة العشوائية. ج. عينة التمييز: تم سحب عينة عشوائية بلغت (، (1) من كلية التربية د. عينة البحث الأساسية:

فبعد تحديد مجتمع البحث تم سحب عينة عشوائية طبقية لان المجتمع غير متجانس أي انه متكون من عدة طبقات تتصف كل منها ببعض الخواص والصفات والتي تميزها بعضها عن

$$
\text { البعض الآخر (حمودي،و، . . ب : (1). }
$$

وسحبت العينة من كليات التمريض والعلوم والتربية والآداب ثم سحبت عينة عشوائية طبقية

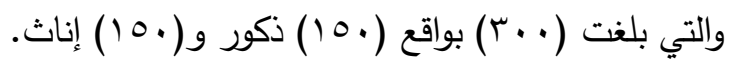
رابعا: أداتا البحث:

لغرض تحقيق أهداف البحث تطلبت الحاجة إلى استخدام أداة لقياس تقديم الذات وأداة لقياس الكفاءة الشخصية للى طلبة الجامعة. 


$$
\begin{aligned}
& \text { جامسعة واسـط }
\end{aligned}
$$

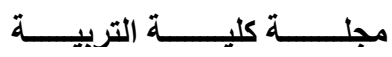

$$
\begin{aligned}
& \text { اولا: أداة تقديم الذات: } \\
& \text { أ - وصف أداة تقديم الذات: }
\end{aligned}
$$

استخدمت الباحثة المقياس الجاهز المعد من قبل (يارنظر وهيثم) لقياس تقديم الذات والذي يتكون من (• م) فقرة ذات بدائل خمسة ب - الصدق: وتم التحقق لنوعين من الصدق.

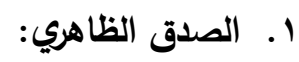

تحقتت الباحثة من الصدق الظاهري للأداة بعرض فقراتها على مجموعة من الخبراء والمحكمين

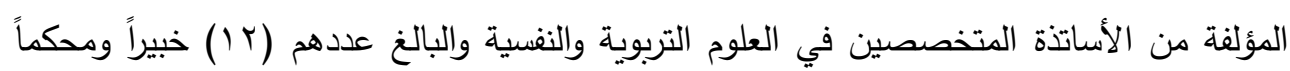

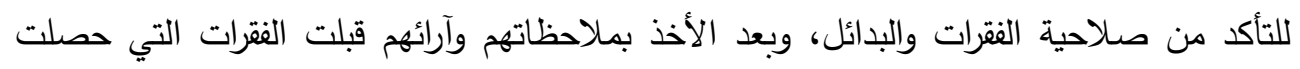

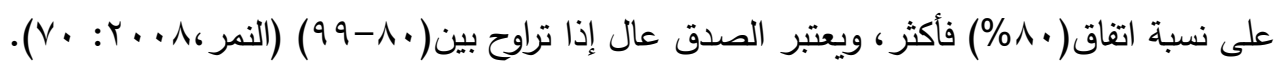

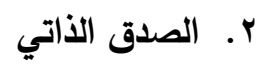
انه صدق الدرجات التجريبية للمقياس بالنسبة للدرجات الحقيقية التي خلصت من أخطاء القياس وبذلك تصبح الدرجات الحقيقية هي الميزان الذي تتسب إليه صدق المقياس والثبات يقوم

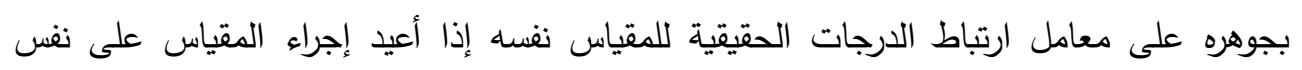

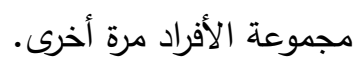
ويحسب الصدق الذاتي بالقانون الآتي :

$$
\begin{aligned}
& \text { معامل الصدثق الأذئي = معامل ثئاث المقياسن } \\
& \text { حيث أن معامل ثبات المقياس = (乏 ^, • ) } \\
& \text { فالصدق الذاتي هو = } 0.916=0.84
\end{aligned}
$$

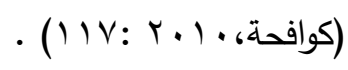

$$
\begin{aligned}
& \text { ج- القوة التمييزية لأداة تقديم الذات }
\end{aligned}
$$

وباستخدام الاختيار التائي لعينتين مستقلتين تم التحقق من دلالة الفرق بين درجات التيات

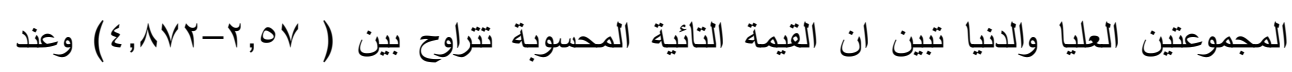

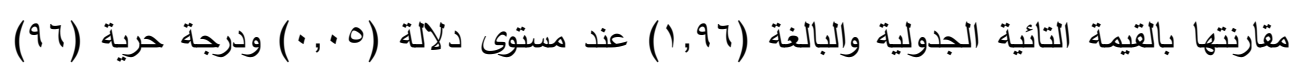
تبين ان جميع الفقرات مميزة. 


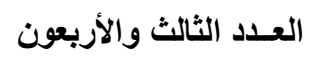

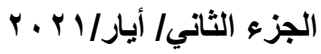

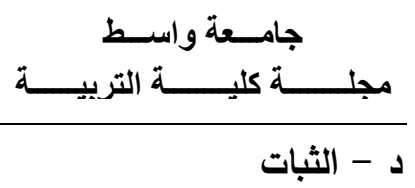

وتحقت الباحثة من ثبات أداة تقديم الذات بطريقة أعادة الإختبار : لمات إذ طبقت الأداة على عينة مؤلفة من ( • 7) طالب وطالبة سحبت بطريقة عشوائية حيث تم اختيارهم من كلية التربية، ثم أعيد تطبيق الاختيار على نفس العينة بعد مضي (10) يوم على التطبيق

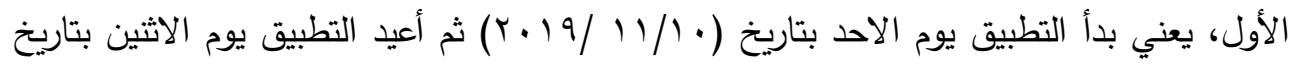

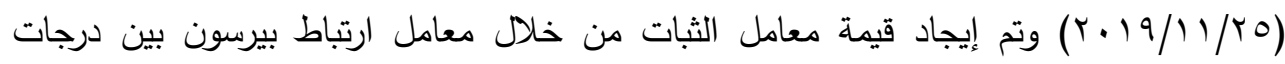
التطبيق الأول والتطبيق الثاني إذ بلغ (ءی, •) وتعد هذه القيمة مؤشرا جيدا على استجابات المقياس

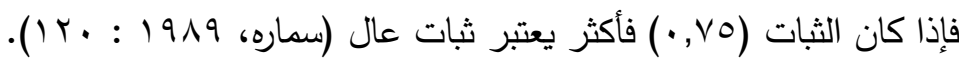
ثانيا: أداة الكفاءة الشخصية: ا ـ إعداد المقياس:

اتبعت الباحثة عدة خطوات في عملية اعداد المقياس وكما يأتي:

أ- الاطلاع على عدد من الأدبيات والدراسات السابقة الخاصة بموضوع الكفاءة الثخصية. ب- وكانت آراء لجنة من الخبراء والمحكمين في قسم العلوم التربوية والنفسية بإعداد أداة لقياس الكفاءة الثخصية فعددت الباحثة إلى إعداد الأداة، تكونت بصورتها الأولية من (Yr) فقرة ذات بدائل خمسة. r. الصدق: ويشير هذا المفهوم الى الاستدلات الخاصة التي نخرج بها من درجات المقياس من حيث مناسبتها ومعناها وفائدتها (ابو علام، 0. . . :00 ) وقد تحققت الباحثة من نوعين لصدق الاداة وكالاتي: - n

أ - أ - الصدق الظاهري:

يقصد به أن المقياس يبدو صادقا بالنسبة للمفحوصين أو لمن ينظر إليه إذا بدا أن الأسئلة

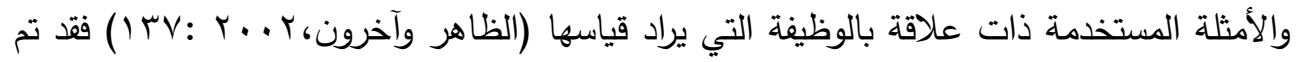
استخراج الصدق الظاهري للأداة بعرض فقرات الكفاءة الشخصية على مجموعة من الخبراء والمحكمين من الأساتذة المتخصصين في العلوم التربوية والنفسية والبالغ عددهم (Y) خبيرا ومحكما للتأكد من صلاحية الفقرات والبدائل وبعد الأخذ بملاحظاتهم وأرائهم قبلت الفقرات التي حصلت على نسبة اتفاق (•^\%) فأكثر ويشير بلوم أن المقياس إذا حصل على نسبة اتفاق (V0)

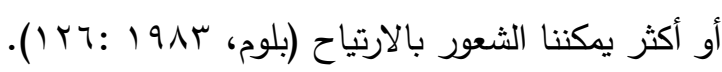


وهو أحد أنواع الصدق ويعرف أيضا بأنه صدق الدرجات التجرببية بالنسبة للدرجات

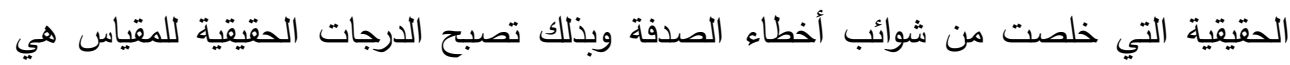
الميزان أو المحك الذي ينسب اليه صدق المقياس • ويحسب الصدق الذاتي بالقانون الاتي:

$$
\begin{aligned}
& \text { معامل الصدق الذاتي = معامل ثبات المقياس } \\
& \text { حيث أن معامل ثبات المقياس = (Yr. . ) } \\
& \text { فالصدق الذاتي هو = } 0.905=0.82
\end{aligned}
$$

وبما أن ثبات المقياس يؤسس على ارتباط الدرجات الحقيقية للمقياس نفسه إذا أعيد تطبيقه على المجموعة نفسها لذا فإن الصلة وثيقة بين الثبات والصدق الذاتي(أبو حويج وآخرون، ج . . Y : I I ).

ب- القوة التمييزية

لغرض حساب قوة تمييز الفقرات لمقياس الكفاءة الشخصية تم إجراء الخطوات الآتية: - تم سحب عينة عشوائية من خارج العينة الأساسية كلية التربية وبلغ عددهم ( • ( ) طالبا وطالبة وترى (Nunnally, 1978) بأن حجم عينة التمييز يمكن ان يكون خمسة أمثال عدد الفقرات

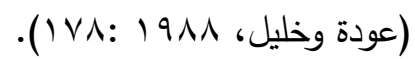

- بعد ذلك قامت الباحثة بتطبيق المقياس ومن ثم تصحيحه وحساب الدرجة الكلية لكل طالب

وطالبة.

- رتبت الاستمارات تتازليا من أعلى درجة إلى ادني درجة ، وقد أوضح كيلي (Kelley) أنه في

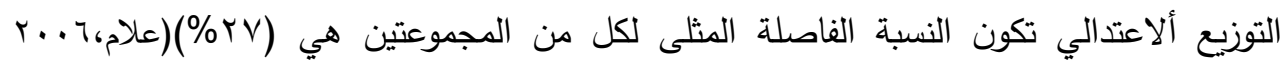
(1):

ولذلك اعتمدت الباحثة نسبة (rv\%) من الدرجات العليا والتي كان عددها (^ی) طالب وطالبة، (V r \%) من الدرجات الدنيا والتي تمثل (^乏) طالب وطالبة وباستخدام الاختبار التائي لعينتين مستقلتين تم التحقق من دلالة الفروق بين درجات المجموعتين (العليا والدنيا) وتبين أن

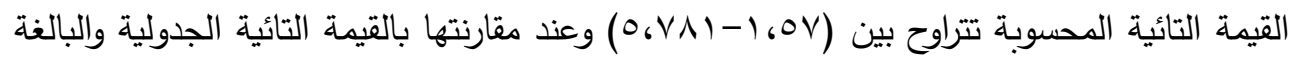

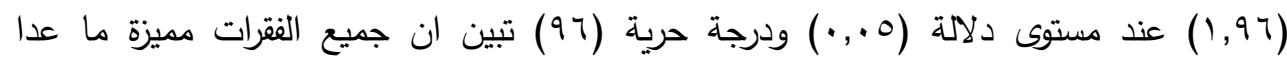
الفقرتين(T ، 1 (1) لذا تم حذفها من الأداة وتكون المقياس بصيغته النهائية من ( • ب) فقرة. 


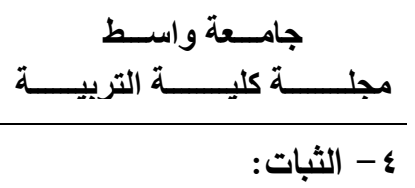

وتحققت الباحثة من ثبات أداة الكفاءة الثخصية بطريقة اعادة الاختبار : إذا طبقت الأداة على عينة عشوائية مؤلفة من ( • 7) طالباً وطالبة سحبت بطريقة عشوائية من طلبة كلية التربية حيث تم اختيار عينة الثبات، ثم أعيد تطبيق الاختيار على نفس العينة بعد مضي

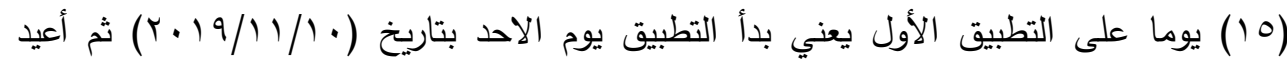

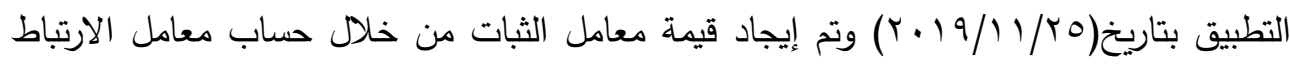
بيرسون بين درجات التطبيق الأول والتطبيق الثاني آذ بلغ (rA, • ) ويعتبر المقياس ثابت إذا تراوح معامل الارتباط ما بين ( • V, •- • 9, • ) لذلك تعتبر قيمة معامل الارتباط جيدة.

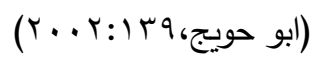

خامسا: التطبيق النهائي بعد تحديد حجم عينة البحث الأساسية والبالغة ( . ب) طالب وطالبة، وبعد التحقق من الصدق الظاهري والذاتي والقوة التمييزية والثبات لأداتي البحث، طبقت على عينة البحث الأساسية

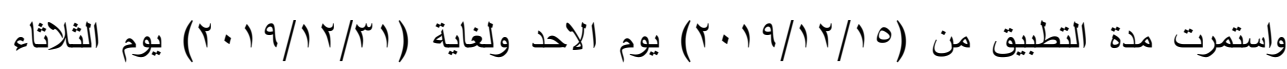
وعندما قامت الباحثة بتطبيق الأداتين بصورتهما النهائية على أفراد العينة حرصت الباحثة بتوضيح الهدف العلمي من البحث وضرورة ان تكون الإجابة صادقة وكاملة لكل الفقرات علما بان إجابتهم سرية ولا تستخدم إلا لأغراض البحث العلمي وبدون ذكر الاسم وتم التوضيح للطلبة بأنه لا توجد إجابة صحيحة وأخرى خاطئة بل ان جميع الإجابات صحيحة ما دامت تعبر عن وجهة نظر الفرد نغسه.

$$
\begin{aligned}
& \text { سادسا: تصحيح أداتي البحث: } \\
& \text { 1- أداة تقديم الذات: }
\end{aligned}
$$

تم تصحيح المقياس على إعطاء الأوزان من (0-1) بالنسبة للفقرات الايجابية ، وإعطاء الأوزان من (1-0) بالنسبة للفترات السلبية وان أعلى درجة للمقياس هي (10.1) وأقل درجة للمقياس هي (•r) والوسط الفرضي (•(9) بعدها تم معالجة البيانات إحصائيا باستخدام الحقيبة الإحصائية SPSS للعلوم الاجتماعية. r - اداة الكفاءة الشخصية: تم تصحيح المقياس على إعطاء الأوزان من (0-1) بالنسبة للفترات الايجابية، وإعطاء الأوزان من (1-0) بالنسبة للفقرات السلبية وان أعلى درجة للمقياس هي (10.1 ) وأقل درجة 


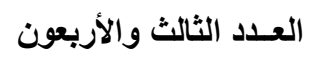

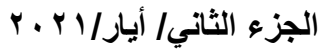

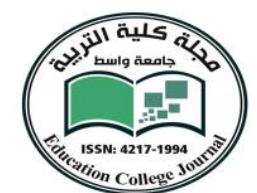

$$
\text { جامسعة واســط }
$$

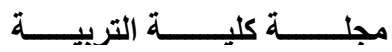

للمقياس هي( • (ب) والوسط الفرضي (·a) بعدها تم معالجة البيانات إحصائيا باستخدام الحقيبة الإحصائية SPSS للعلوم الاجتماعية. سابعاً : الوسائل الإحصائية

لإستخراج نتائج البحث فقد استعانت الباحثة بالحقيبة الإحصائية للعلوم التربوية (SPSS) فضلاً عن استخدامها الوسائل الإحصائية الآتية : أ- اختبار التائي لعينة واحدة . ب- الاختبار الزائي لعينين مستقلتين. ت- الاختبار التائي لدلالة معامل الارتباط.

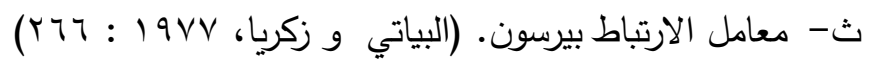
عرض النتائج ومناقشتها:

الهاف الأول : تعرف مستوى تقديم الذات لاى طلبة الجامعة لأجل تحقيق هذا الهدف تم استخراج المتوسط الحسابي لأفراد عينة البحث البالغ عددهم

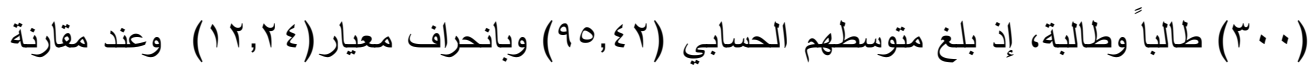
المتوسط الحسابي مع المتوسط الفرضي والبالغ ( •9) تبين أن المتوسط الحسابي للعينة اكبر من المتوسط الفرضي ولغرض التعرف على دلالة الفرق بين المتوسطين الحسابي والفرضي طبقت الباحثة الاختبار التائي لعينة واحدة ( one sample t-test) إذ بلغت القيمة التائية

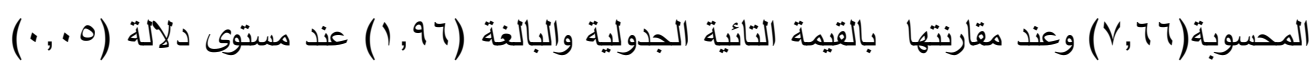
وبدرجة حرية (q9) تبين أن القيمة التائية المحسوبة اكبر من القيمة التائية الجدولية والجدول (r) يبين ذلك.

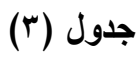

نتائج مقارنة المتوسط الحسابي والمتوسط النظري لمقياس تقديم الذات لاى طلبة الجامعة

\begin{tabular}{|c|c|c|c|c|c|c|c|}
\hline \multirow[t]{2}{*}{ الدلالة } & \multicolumn{2}{|c|}{ القيمة التائية } & \multirow{2}{*}{ المتوسط } & \multirow{2}{*}{ الانحراف } & \multirow{2}{*}{ المتوسط الحسابي } & \multirow[t]{2}{*}{ العينة } & \multirow[t]{2}{*}{ المتغير } \\
\hline & الجدولية & المحسورة & & & & & \\
\hline دالة & 1,97 & $V, 74$ & 9. & $\mid r, r \varepsilon$ & $90, \Sigma r$ & r.. & تقديم الذات \\
\hline
\end{tabular}

وتثير النتيجة إلى وجود فرق دال معنويا في مقياس تقديم الذات ولصالح أفراد عينة البحث واتضح كذلك ان درجات أفراد العينة تقع ضمن المستوى المتوسط من مستويات تقديم الذات 
الهاف الثاني : تعرف مستوى الكفاءة الثخصية لاى طلبة الجامعة

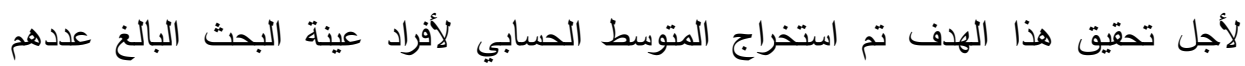

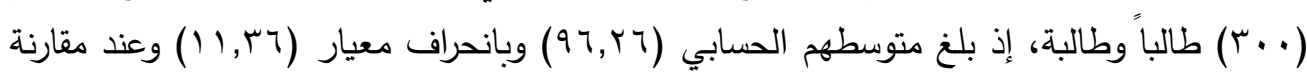

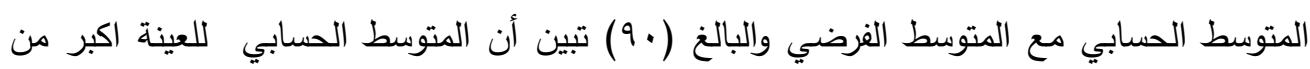

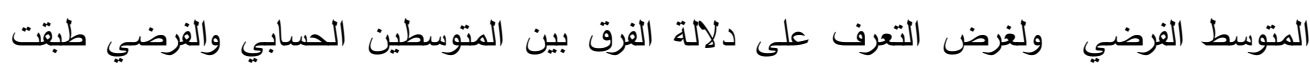

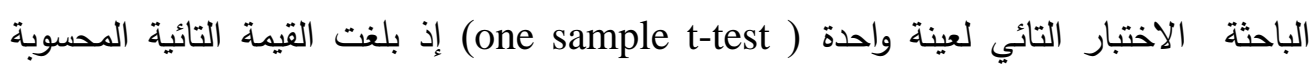

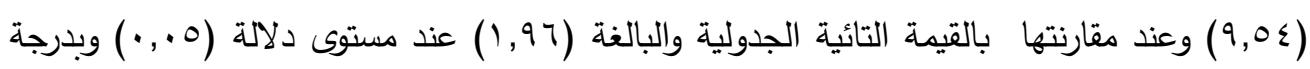

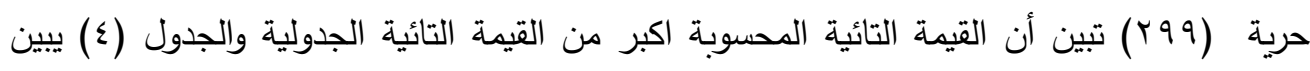
ذلك.

\section{جلول (؛)}

نتائج مقارنة المتوسط الحسابي والمتوسط النظري لمقياس الكفاءة الشخصية لاى طلبة الجامعة

\begin{tabular}{|c|c|c|c|c|c|c|c|}
\hline \multirow{2}{*}{ مستوى الدلالة } & \multicolumn{2}{|c|}{ القيمة التائية } & \multirow{2}{*}{ النظتوسط } & \multirow{2}{*}{ الانحراف } & \multirow{2}{*}{ المتوسط } & \multirow[t]{2}{*}{ العينة } & \multirow[t]{2}{*}{ المتغير } \\
\hline & الجدولية & المحسوبة & & & & & \\
\hline دالة & 1,97 & $9,0 \leqslant$ & 9. & 11,49 & $97, Y 9$ & $r \ldots$ & الكخفاءة \\
\hline
\end{tabular}

وتثير النتيجة إلى وجود فرق دال معنويا في مقياس الكفاءة الثخصية ولصالح أفراد عينة البحث واتضح كذلك ان درجات أفراد العينة تقع ضمن المستوى المتوسط من مستويات الكفاءة الثخصية.

الهدف الثالث : تعرف العلاقة بين تقديم الذات والكفاءة الثخصية لدى طلبة الجامعة لأجل تحقيق هذا الهدف استخرجت الباحثة قيمة معامل ارتباط بيرسون بين استجابات افراد العينة

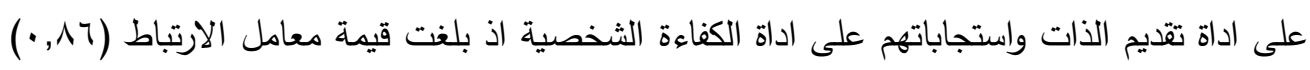

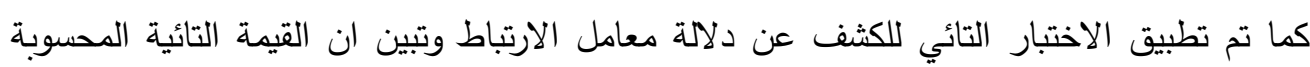

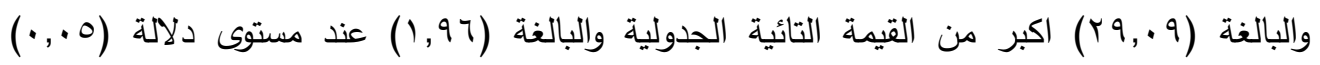
وبدرجة حرية (Y१) والجدول (0) يبين ذلك. 


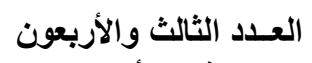

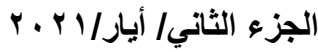

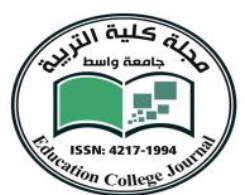

جامسعة واستط

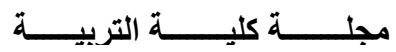

جدول (0)

يوضح طبيعة العلاقة الارتباطية بين تقديم الذات والكفاءة الشخصية لاى طلبة الجامعة

\begin{tabular}{|c|c|c|c|c|}
\hline \multirow{2}{*}{ مستوى الدلالة } & \multicolumn{2}{|c|}{ القيمة التائية } & معامل & \multirow[t]{2}{*}{ المتغــــــــــير } \\
\hline & الجدولية & المحسوبة & الارتباط & \\
\hline دالة & 1,97 & $r q, . q$ & • & تقديم الذات × الكفاءة الثخصية \\
\hline
\end{tabular}

وتثير هذ النتيجة الى وجود علاقة ارتباطية دالة احصائيا بين تقديم الذات والكفاءة الثخصية لاى

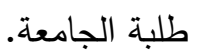

الههف الرابع: تعرف الفروق ذات الدلالة الاحصائية في العلاقة بين تقديم الذات لاى طلبة الجامعة

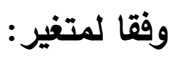

- الجنس (ذكور- إناث) : لغرض تحقيق هذا الهدف طبقت الباحثة الاختبار التائي لعينتين مستقلتين (Tow samples Independent T-Test)

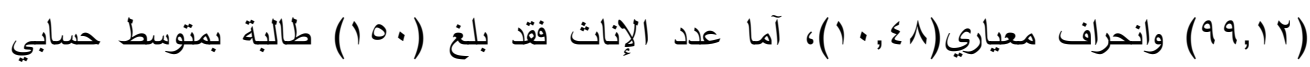

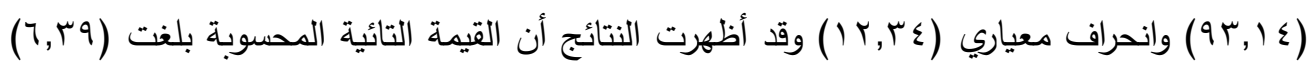

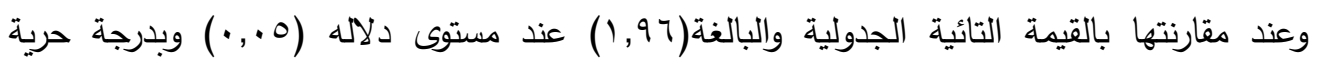
(Y9^) فرقا دالاً إحصائيا في مستوى تقديم الذات لدى طلية البة الجامعة وفقاً لدتغير الجنس(ذكور - إناث) ولصالح الذكور والجدول (†) يبين ذلك.

\section{جدول (†)}

نتائج الاختبار التائي لعينتين مستقلتين لالالة الفروق في مستوى تقديم الذات لاى طلبة الجامعة تبعاً لمتغيرات الجنس (ذكور - إناث ) والتخصص (علمي- إنساني)

\begin{tabular}{|c|c|c|c|c|c|c|c|}
\hline \multirow{2}{*}{ مستوى الدلالة } & \multicolumn{2}{|c|}{ القيمة الزائية } & \multirow{2}{*}{ الانحراف } & \multirow{2}{*}{ المستوسط } & \multirow{2}{*}{ الحرية } & \multirow[t]{2}{*}{ العدد } & \multirow[t]{2}{*}{ المتغيرات } \\
\hline & الجدولية & المحسوبة & & & & & \\
\hline \multirow[t]{2}{*}{ دالة } & \multirow[t]{2}{*}{1,97} & \multirow[t]{2}{*}{$7, r 9$} & $1 \cdot, \leqslant \Lambda$ & $99,1 r$ & \multirow{4}{*}{ rqA } & 10. & ذكور \\
\hline & & & IT,r & $94,1 \leq$ & & 10. & إناث \\
\hline \multirow[t]{2}{*}{ غير دالة } & \multirow[t]{2}{*}{1,97} & \multirow[t]{2}{*}{$1, r}$. & $11,0 r$ & 90,91 & & 10. & علمي \\
\hline & & & Ir,Tr & $9 \leq, \wedge \uparrow$ & & 10. & إنساني \\
\hline
\end{tabular}


- التخصص (علي- إنساني) : لغرض تحقيق هذا الهدف طبقت الباحثة الاختبار التائي لعينتين مستقلتين (Tow samples Independent T-Test) حيث بلغ عدد طلبة الأقسام العلمية (10.) (10) طالباً وطالبة بمتوسط حسابي (90,91) وانحراف معياري (1,0r(1)، آما عدد طلبة الأقسام الانسانية

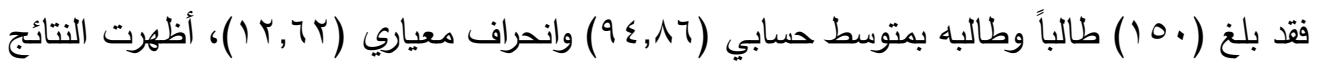
أن القيمة التائية المحسوبة بلغت (•r, l) وعند مقارنتها بالقيمة التائية الجدولية والبالغة (79, I) عند

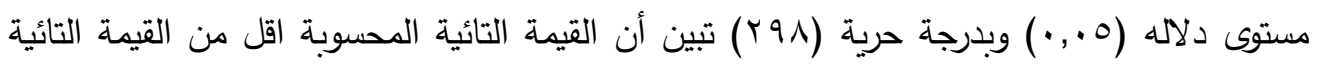
الجدولية وتدل هذه النتيجة على عدم وجود فرقا دالا إحصائيا في مستوى تقديم الذات لدى طلبة الجامعة وفقاً لمتغير التخصص (علمي- إنساني) والجدول (7) يبين ذلك. الهدف الخامس: تعرف الفروق ذات الالالة الاحصائية في العلاقة بين الكفاءة الشخصية لاى ولى طلبة الجامعة وفقا لمتغير: - الجنس (ذكور - إناث) : لغرض تحقيق هذا الهدف طبقت الباحثة الاختبار التائي لعينتين مستقلتين (Tow samples Independent T-Test) حيث بلغ عدد الذكور (10.0) طالباً بمتوسط

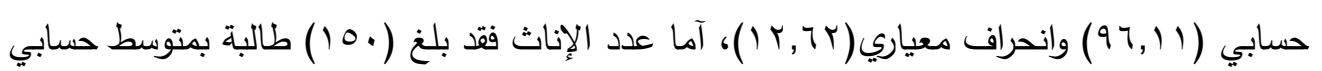

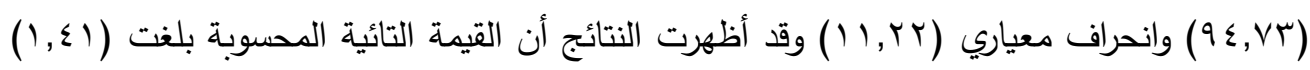
وعند مقارنتها بالقيمة التائية الجدولية والبالغة(7,97) عند مستوى دلاله (0., •) وبدرجة حرية

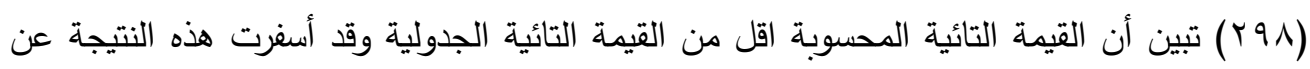
عدم وجود فرقا دالاً إحصائيا في مستوى الكفاءة الثخصية لدى طلبة الجامعة وفقاً لمتغير الجنس لئس (ذكور - إناث) والجدول (V) يبين ذلك.

(v) جدول

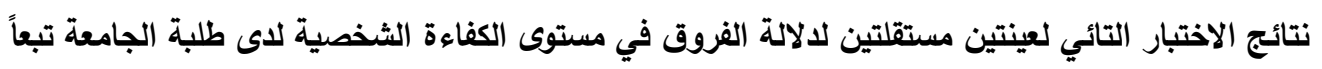
لمتغيرات الجنس (ذكور - إناث ) والتخصص (علمي- إنساني)

\begin{tabular}{|c|c|c|c|c|c|c|c|c|}
\hline \multirow{2}{*}{\multicolumn{2}{|c|}{ مستوى الالالة }} & \multicolumn{2}{|c|}{ القيمة الزائية } & \multirow{2}{*}{ الانحراف } & \multirow{2}{*}{ المتوسط الحسابي } & \multirow{2}{*}{ الحرية } & \multirow[t]{2}{*}{ العدد } & \multirow[t]{2}{*}{ المتغيرات } \\
\hline & & الجدولية & المحسوبة & & & & & \\
\hline \multirow{2}{*}{\multicolumn{2}{|c|}{ غير دالة }} & \multirow[t]{2}{*}{1,97} & \multirow[t]{2}{*}{$1, \varepsilon 1$} & Ir,Tr & 97,11 & \multirow{4}{*}{ rqA } & 10. & ذكور \\
\hline & & & & $11, r r$ & $q \varepsilon, V T$ & & 10. & إناث \\
\hline \multirow{2}{*}{\multicolumn{2}{|c|}{ غير دالة }} & \multirow[t]{2}{*}{1,97} & \multirow[t]{2}{*}{$1, V}$. & אד, זו & $9 \vee, \cdot 7$ & & 10. & علمي \\
\hline & & & & 1. & $90, \leqslant 7$ & & 10. & \\
\hline
\end{tabular}


- التخص (علي- إنساني) : لغرض تحقيق هذا الهدف طبقت الباحثة الاختبار التائي لعينتين

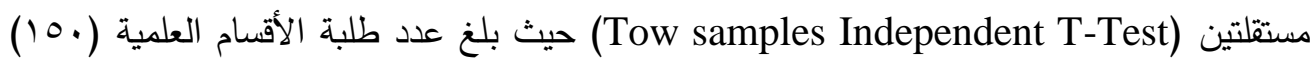

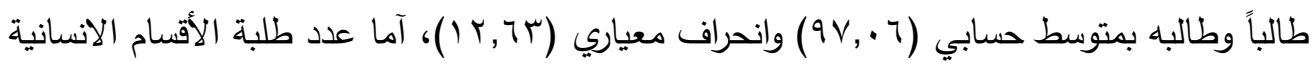

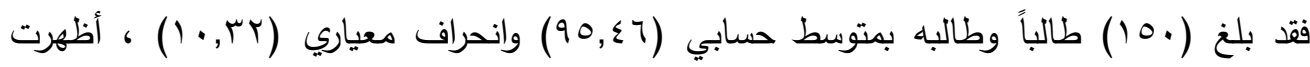

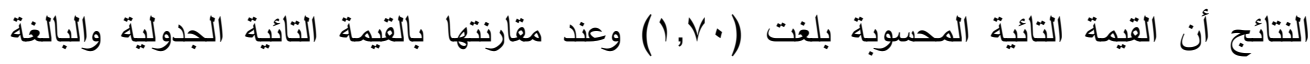

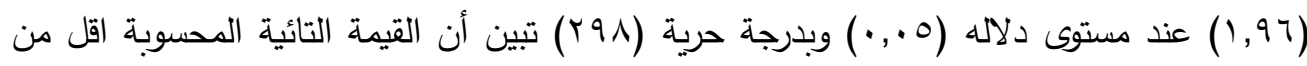

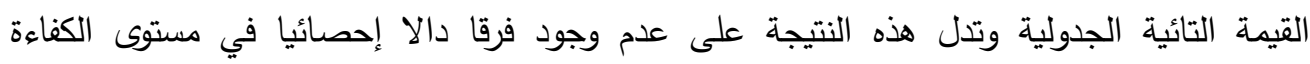

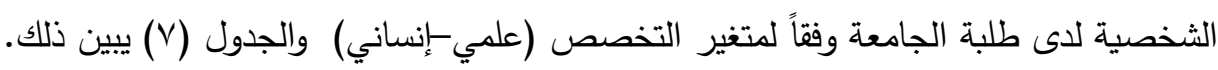

| - الاستنتاجات ا. ان عينة البحث من طلبه الجامعة يتمتعون بمستوى متوسط من تقديم الذات. r. ان عينة البحث من طلبه الجامعة يتمتعون بمستوى متوسط من الكفاءة الثخصية.

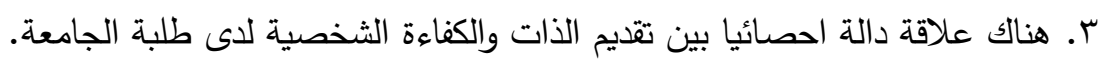

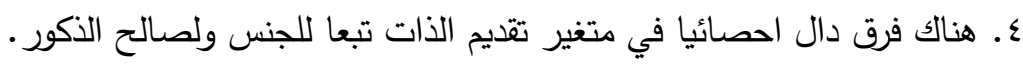

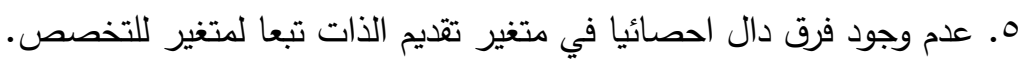
T. عدم وجود فرق دال احصائيا في متغير الكفاءة الثخصية تبعا للجنس والتخصص.

التوصيات: توصي الباحثة بالآتي ا ـ. ضرورة اهتمام وزارة التعليم العالي بإقامة دورات تسهم في رفع مستوى تقديم الذات لاى الطلبة.

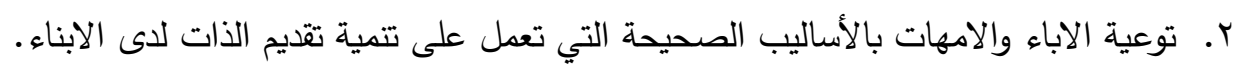

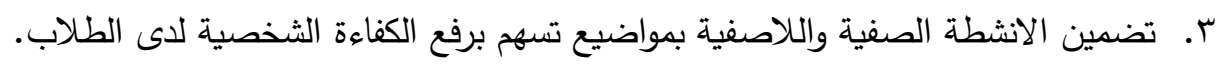

$$
\text { المقترحات: أجراء الدراسات الآتية }
$$

ا ـ تقديم الذات وعلاقته بالإنجاز الدراسي لاءى طلبة الجامعة. r. اثر برنامج تربوي في تتمية تقديم الذات والكفاءة الثخصية لاى طلبة لإلبة الجامعة.

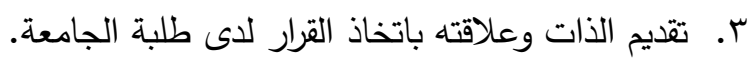
ع. الكفاءة الثخصية وعلاقتها بجودة الحياة الاكاديمية. 


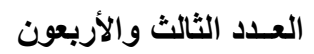

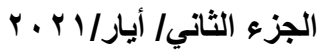

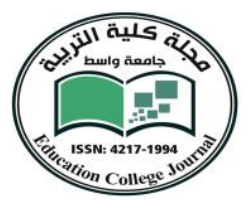

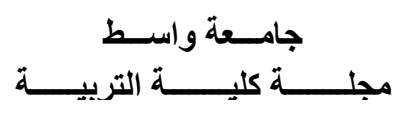

المصادر العربية

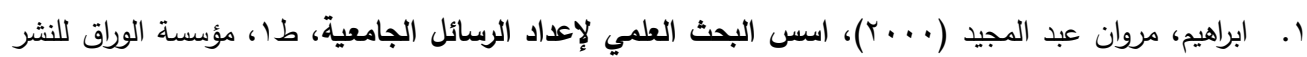

والتوزيع ، الاردن.

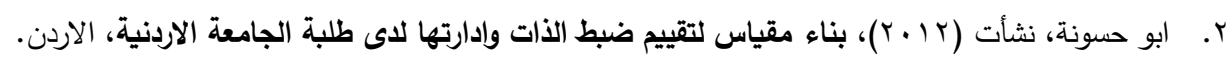

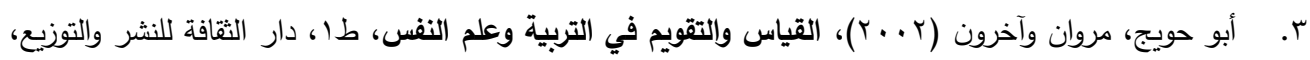
عمان.

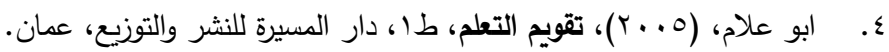

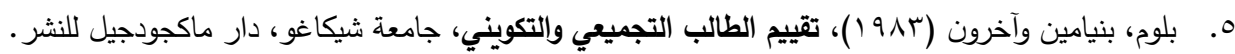

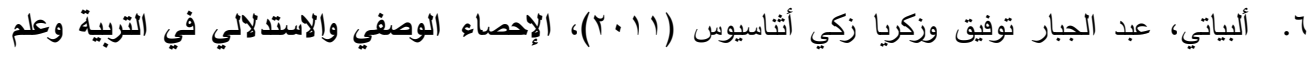
النفس، طץ، دار ابن الأثير للطباعة والنشر ، الموصل، العراق.

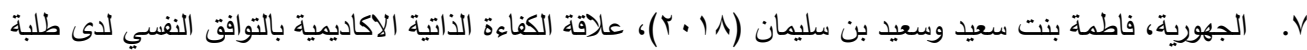

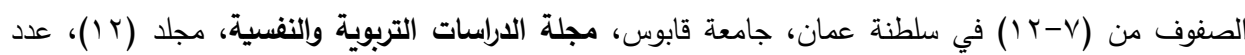

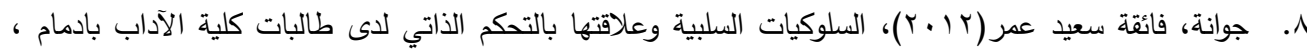

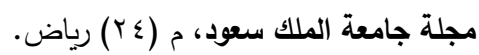

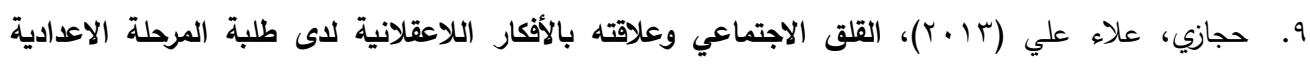

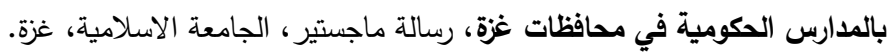

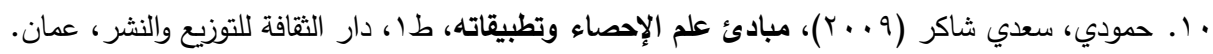

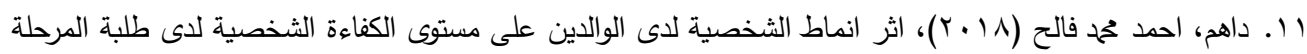

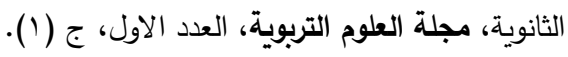

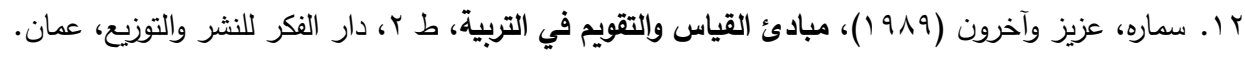

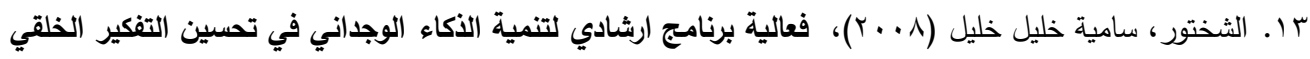
واستراتيجات تقديم الذات لاى المراهقين، اطروحة دكتوراه، جامعة الزقازيق.

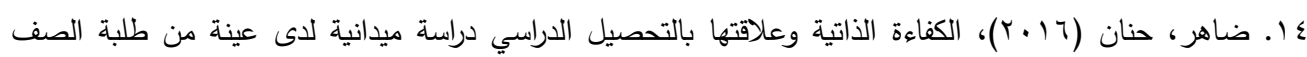

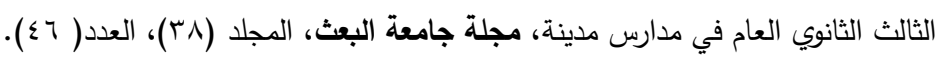

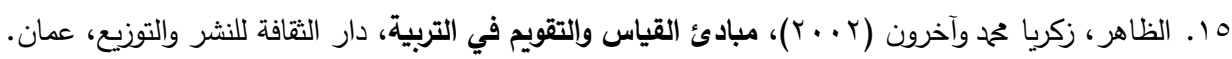

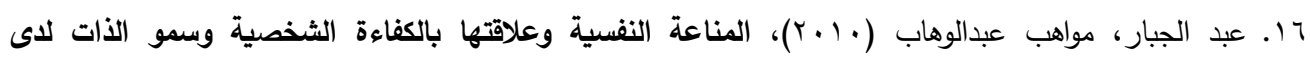
المصابين بمرض الغذة الدرقية، اطروحة دكتوراه، جامعة المستنصرية العراق.

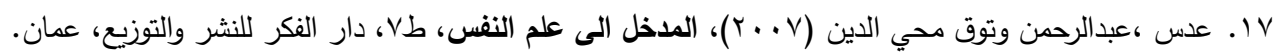

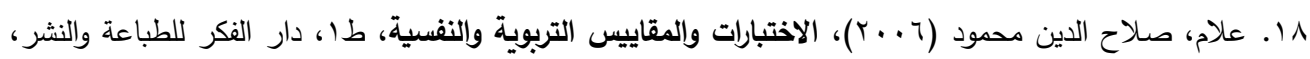
عمان. 


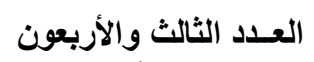

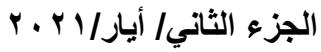

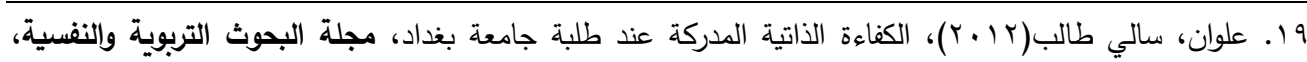

$$
\text { العدد (الثالث والثلاثون ). }
$$

•r. r. العوافي، احمد (ب ت)، عرض الذات في الحياة اليومية.

www.Asofiom@gmail.com

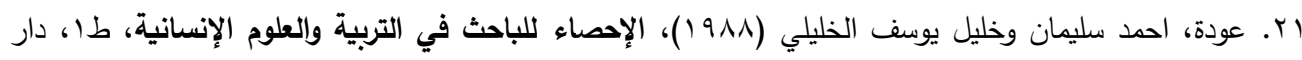
الفكر للطباعة والنشر، عمان. بww.Asofiom@gmail.com

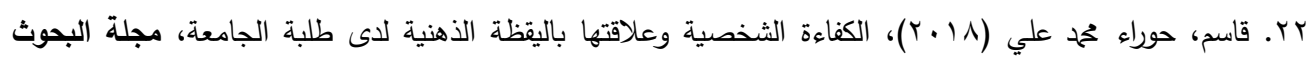

$$
\text { التربوية والنفسية، العدد(YV) (YV). }
$$

rr. الكعبي، سهام مطشر (1) (Y)، سيكولوجية تقديم الذات لدى النساء ،جامعة بغداد ، مركز البحوث النفسية العدد

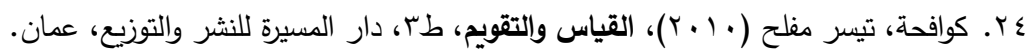

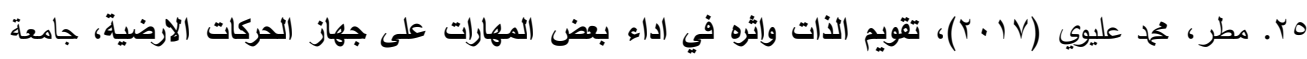
القادسية، كلية التربية البدنية وعلوم الرياضة.

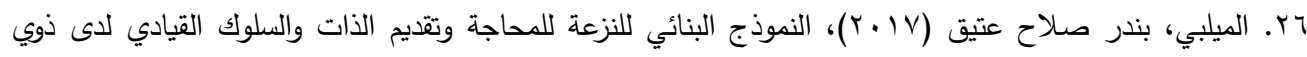

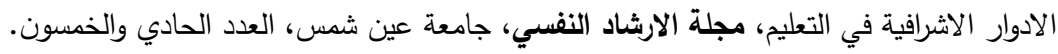

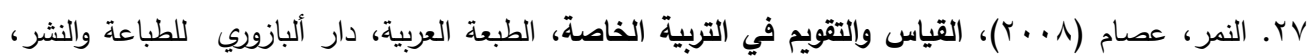
عمان.

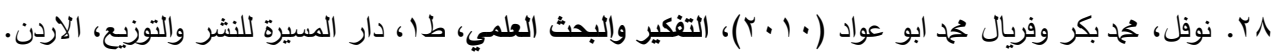

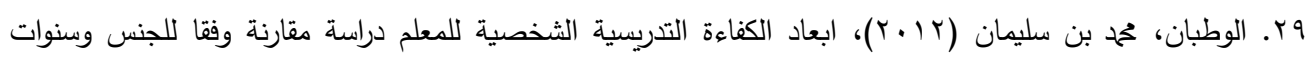

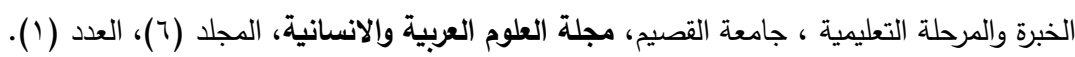

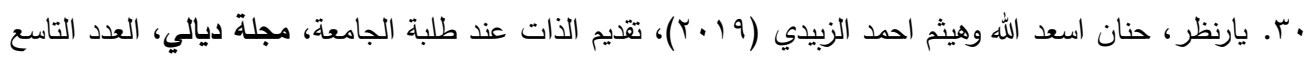
والسبعون. 


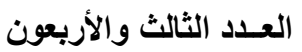

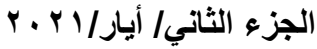
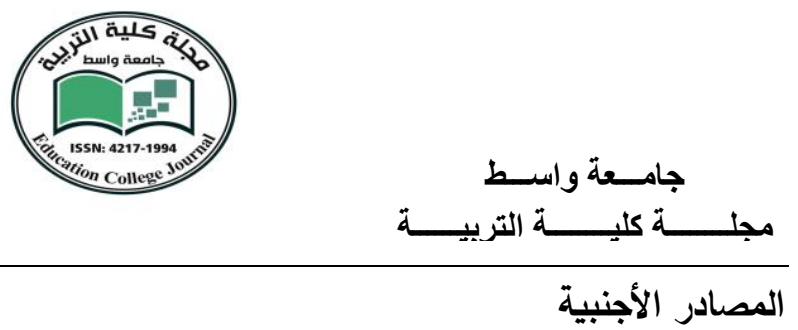

31. Arkin R.m ape- man A.J\& Burger J.M (1980), Social anxiety, self -Presentation and self - serving bias in causal attribution, Journal of personality and social psychology, vol.38 No 1.

32. Heino,(2006), Self-Presentation in online personals The Role of Anticipated future Interaction , Self -Disclosure ,and Perceived Success in Internet Dating , Communication Research, Volume (33) Number(2)

33. Honoree(1999), personality and Impression Interactionist Perspective. A Doctor of Philosophy.

34. Zarghooni ,Sasan (2007), A Study of Self - Presentation in Light of Facebook Institute of Psychology, University of Oslo. 